\title{
SISTEM PENDUKUNG KEPUTUSAN MAHASISWA BERPRESTASI MENGGUNAKAN METODE SAW PADA UNIVERSITAS MUSAMUS
}

\author{
Susanto $^{1}$, Nilfred Patawaran ${ }^{2}$ \\ ${ }^{1,2}$ Jurusan Teknik Informatika, Fakultas Teknik, Universitas Musamus \\ Email : ${ }^{1}$ tuansanto@yahoo.co.id,${ }^{2}$ nilfred.patawaran@unmus.ac.id
}

\begin{abstract}
ABSTRAK
Universitas Musamus (UNMUS) adalah perguruan tinggi negeri di Kabupaten Merauke, Provinsi Papua yang diresmikan pada tanggal 22 november 2010 oleh Presiden Republik Indonesia Bapak Dr. H. Susilo Bambang Yudhoyono. Biro Akdademik, Kemahasiswaan dan Kerja sama (BAKK) merupakan biro yang menangani kegiatan seleksi pemilihan mahasiswa berprestasi pada UNMUS. Proses pemilihan mahasiswa berprestasi yang dilakukan selama ini masih memiliki beberapa kendala, sehingga menimbulkan beberapa persoalan yaitu, proses pengolahan data pemilihan yang memerlukan waktu yang lama dan belum adanya penyimpanan data mengenai proses pemilihan mahasiswa berprestasi. Tujuan penelitian untuk membantu dalam mempercepat proses pengolahan data pemilihan mahasiswa berprestasi dan dapat menyimpan data proses pemilihan mahasiswa berprestasi.

Sistem yang dirancang adalah sistem pendukung keputusan pemilihan mahasiswa berprestasi berbasis web yang menggunakan bahasa pemrograman PHP dan Xampp sebagai server localhost atas program Apache HTTP server, MySQL database dan penerjemah bahasa pemrograman PHP. Pengujian sistem yang dilakukan pada sistem ini menggunakan metode Black Box dan Pengujian perbandingan perhitungan SAW.

Hasil dari pengujian menggunakan Black Box dan Pengujian perbandingan perhitungan SAW didapatkan bahwa, sistem pendukung keputusan pemilihan mahasiswa berprestasi pada Universitas Musamus dapat mempercepat proses pengolahan data pemilihan mahasiswa berprestasi dan dapat menyimpan data proses pemilihan mahasiswa berprestasi.
\end{abstract}

Kata Kunci : Sistem Pendukung Keputusan, Mahasiswa berprestasi, SAW, Universitas Musamus.

\section{PENDAHULUAN}

Perguruan Tinggi merupakan tempat mahasiswa untuk mencari ilmu sesuai dengan bakat dan minat. Pada lapisan perguruan tinggi ada salah satu program pemilihan mahasiswa berprestasi yang berguna untuk memilih mahasiswa terbaik yang memiliki kemampuan prestasi dibidang akademik dan non akademik pada suatu perguruan tinggi. Mahasiswa berprestasi wajib menyelesaikan beberapa kriteria secara akademik maupun non akademik. Kriteria akademik meliputi indeks prestasi kumulatif, sedangkan kriteria non akademik meliputi kepanitian, keaktifan dalam keorganisasian, prestasi kejuaraan atau kegiatan ekstrakurikuler yang lain [1].

Universitas Musamus (UNMUS) adalah perguruan tinggi negeri di Kabupaten Merauke, Provinsi Papua yang diresmikan pada tanggal 22 november 2010 oleh Presiden Republik Indonesia Bapak Dr. H. Susilo Bambang Yudhoyono [2]. Biro Akademik, Kemahasiswaan dan Kerja sama (BAKK) merupakan biro yang menangani 
kegiatan seleksi pemilihan mahasiswa berprestasi pada UNMUS. Kriteria yang digunakan ditentukan oleh kesepakatan tim juri (penilai) berdasarkan pedoman oleh Dirjen Dikti, kriteria tersebut adalah IPK, Karya Tulis, Prestasi akademik maupun non akademik dan Bahasa Inggris

Proses pemilihan mahasiswa berprestasi yang dilakukan selama ini masih memiliki beberapa kendala sehingga menimbulkan beberapa persoalan yaitu proses pengolahan data pemilihan yang memerlukan waktu lama, memungkinkan terjadinya human error pada proses pengolahan data yang digunakan dalam proses pemilihan dan memungkinkan kurangnya informasi mengenai data pemilihan mahasiswa berprestasi yang tidak sesuai dengan jumlah data. informasi yang dimaksudkan adalah informasi dari hasil proses pemilihan mahasiswa berprestasi yang telah dilakukan. Informasi yang diperoleh dari hasil proses pemilihan mahasiswa seharusnya dapat dipergunakan dengan baik, sehingga memudahkan pihak BAKK untuk melakukan kebijakan yang akan dilakukan dimasa mendatang.

Metode SAW (Simple Additive Weighting) merupakan metode yang digunakan dalam sistem pendukung keputusan, konsep dasar dari metode ini adalah mencari penjumlahan terbobot dari rating kinerja setiap alternatif pada semua atribut [3]. Dengan metode ini penilaian akan lebih tepat karena didasarkan pada nilai kriteria dan bobot yang sudah ditentukan, sehingga hasil pemilihan mahasiswa berprestasi lebih akurat.

Berdasarkan permasalahan maka akan dibuat sistem dengan judul "Sistem Pendukung Keputusan Pemilihan Mahasiswa Berprestas Menggunakan Metode SAW Pada Universitas Musamus", dengan mengambil sampel mahasiswa berprestasi pada Fakultas Teknik, dan diharapkan dapat membantu pihak BAKK dalam menentukan mahasiswa berprestasi.

\section{TINJAUAN PUSTAKA}

\subsection{Penelitian Terdahulu}

Penelitian yang dilakukan Frieyadie, (2016), dalam judul penelitiannya "Penerapan Metode Simple Additive Weight (SAW) Dalam Sistem Pendukung Keputusan Promos Kenaikan Jabatan" sistem yang dihasilkan dari aplikasi tersebut adalah sistem pendukung keputusan yang dapat membantu pimpinan dan pihak SDM dalam menentukan keputusan terkait promosi kenaikan jabatan seorang karyawan untuk posisi tertentu sesuai dengan syarat dan kebutuhan perusahaan [3].

Penelitian yang dilakukan M. Hindayati dkk. (2017), dalam penelitiannya "Sistem Pendukung Keputusan Penentuan Mahasiswa Berprestasi di Universitas Muhammadiyah Purwokerto Menggunakan Metode Weighted Product (WP)" sistem yang dihasilkan dari aplikasi tersebut yaitu memudahkan pihak BAK dalam memilih mahasiswa berprestasi dan mengatasi terjadinya kesalahan dalam proses pengolahan data pemilihan mahasiswa berprestasi [4].

Penelitian yang dilakukan E.Sri (2011), dalam penelitiannya yang berjudul "Perancangan Sistem Pendukung Pengambilan Keputusan untuk Penerimaan Beasiswa dengan Metode SAW (Simple Additive Weighting)" sistem yang dihasilkan dari aplikasi tersebut adalah membuat SPK penerimaan calon beasiswa untuk mempermudah kinerja yang bertugas dalam penerimaan beasiswa [5].

\subsection{Sistem Pendukung Keputusan}


SPK ialah sistem informas khusus untuk membantu pengguna mengambil tindakan berkaitan dengan masalah secara tepat dan benar serta tidak mengubah kegunaan dar pengambilan keputusan dalam membuat keputusan [6].

\subsection{Mahasiswa Berprestasi}

Mahasiswa berprestas ialah mahasiswa yang dapat meraih prestas akademik yang tingg dalam bidang ilmu, teknolog atau sen yang ditekuninya, aktif dalam kegiatan intraekstrakurikuler sehingga patut dibanggakan dan berjiwa Pancasila [1].

\subsection{SAW (Simple Additive Weighting)}

Menurut Fishburn dan MacCrimmon dalam penelitian Frieyadie, mengemukakan bahwa Metode SAW (Simple Additive Weighting), biasa juga dikenal dengan istilah metode penjumlahan terbobot. Konsep dasar metode SAW adalah mencar penjumlahan terbobot dar rating kinerja pada setiap alternatif pada semua atribut [3].

Rumus metode SAW :

$\mathrm{rij}=\left\{\begin{array}{l}\frac{\mathrm{xij}}{\operatorname{Max} \mathrm{xij}} \text { jika } \mathrm{j} \text { adalah atribut keuntungan (benefit) } \\ \frac{\text { Min xij }}{\mathrm{xij}} \text { jika j adalah atribut biaya (cost) }\end{array}\right.$

Keterangan :

$\mathrm{r}_{\mathrm{ij}}=$ nila rating kinerja normalisasi

$\mathrm{x}_{\mathrm{ij}}=$ nila atribut yang dimilik dar setiap kriteria

Mix $x i j=$ nila terkecil dar setiap kriteria

Max $x i j=$ nila terbesar dar setiap kriteria

Benefit $=$ nila terbesar adalah terbaik

Cost $=$ nila terkecil adalah terbaik

Dimana $r_{i j}$ adalah rating kinerja ternormalisas dar alternative A pada atribut $\mathrm{Cj} ; \mathrm{i}=1,2, \ldots, \mathrm{m}$ dan $\mathrm{j}=1,2, \ldots, \mathrm{n}$

Nilai preferens untuk setiap alternatif (Vi) diberikan sebagai:

$$
\mathrm{Vi}=\sum_{j=1}^{n} \mathrm{~W}_{i} \mathrm{r}_{\mathrm{ij}}
$$

Keterangan :

$\mathrm{v}=$ Nila akhir alternative

$\mathrm{Wj}=$ Bobot yang telah ditentukan

rij = Normalisas matriks

Nilai V yang lebih besar mengindikasikan bahwa alternative a lebih terpilih.

\subsection{Black Box}

Testing yang berfokus pada spesifikas fungsional dar perangkat lunak alah Black Box. Tester dapat mendefinisikan kumpulan kondis nput dan melakukan pengetesan pada spesifikas fungsional program [7]. Metode pengujian yang digunakan dalam sistem penjadwalan perkuliahan ini adalah metode BlackBox dan metode kuisioner untuk memastikan sistem dapat berfungsi sesuai dengan yang diharapkan [8]

\section{METODE PENELITIAN}

\subsection{Bahan Penelitian}

Penelitian ini menggunakan metode pengambilan data menggunakan cara :

1. Observasi

Observas ketempat langsung yaitu lembaga BAKK pada UNMUS untuk mendapatkan nformasi lebih lengkap mengenai informasi yang terkait dengan penelitian ini.

2. Wawancara

Wawancara yaitu dengan melakukan wawancara terhadap pimpinan/staf lembaga BAKK pada UNMUS guna mencari data pendukung untuk membangun sistem yang ada dan data pendukung lainnya yang terkait dengan pengembangan sistem pendukung keputusan pemilihan mahasiswa berprestasi menggunakan metode SAW pada Universitas Musamus.

3. Studi Pustaka 
Pada penelitian ini dimulai dengan studi kepustakaan yaitu mengumpulkan bahan-bahan referensi baik dari buku, artikel, jurnal, makalah, maupun situs internet mengenai Simple Additive Weighting (SAW), serta bahan pemograman untuk pembuatan aplikasinya, dan beberapa referensi lainnya.

3.2 Analisis kriteria penilaian Mahasiswa Berprestasi

Analisa kriteria penilaian mahasiswa berprestasi disimbolkan dengan (C), Kriteria penilaian pemilihan mahasiswa berprestasi terbagi menjadi 4 kriteria yaitu : IPK (Indeks Prestasi Kumulatif) (C1), Karya Tulis (C2), Prestasi (C3) dan Bahasa Inggris (C4).

Pembobotan kriteria disimbolkan dengan (w), dalam sistem pendukung keputusan pemilihan mahasiswa berprestasi menggunakan metode SAW pada Universitas Musamus, diperoleh nilai pembobotan sebagai berikut :

Tabel 1 Kriteria dan Nilai Bobot

\begin{tabular}{|l|c|}
\hline Nama Kriteria (C) & Nilai Bobot (w) \\
\hline IPK & $20 \%$ \\
\hline Karya Tulis & $30 \%$ \\
\hline Prestasi & $25 \%$ \\
\hline Bahasa Inggris & $25 \%$ \\
\hline
\end{tabular}

\subsection{Struktur tabel database}

Relasi antar tabel dilihat pada gambar 1, terdapat beberapa relasi yang terjadi pada antar tabel-tabel, diantaranya :

1. Tabel fak dengan tabel jur

Relasi ini dibuat karena field id_fak pada tabel jur membutuhkan id_fak dari tabel fak (fakultas), sebagai data fakultas untuk mendapatkan hubungan antar data fakultas dan data jurusan.

2. Tabel jur dengan tabel cal_mawapres
Relasi ini dibuat karena field id_jur pada tabel cal_mawapres membutuhkan id_jur dari tabel jur (jurusan) sebagai data jurusan untuk kelengkapan biodata calon mahasiswa berprestasi.

3. Tabel suku dengan tabel

Relasi ini dibuat karena field id_sk pada tabel cal_mawapres membutuhkan id_sk dari tabel suku, sebagai data suku untuk kelengkapan biodata calon mahasiswa berprestasi.

4. Tabel cal_mawapres dengan tabel nilai

Relasi ini dibuat karena field id_mawapres pada tabel nilai membutuhkan id_mawapres dari tabel cal_mawapres, sebagai data calon mahasiswa berprestasi untuk melakukan penilaian.

5. Tabel bobot dengan tabel nilai

Relasi ini dibuat karena field id_bobot pada tabel nilai membutuhkan id_bobot dari tabel bobot, sebagai data bobot untuk melakukan penilaian.

\section{Tabel nilai dengan tabel hasil}

Relasi ini dibuat karena field id_nilai pada tabel hasil membutuhkan id_nilai dari tabel nilai, sebagai data nilai untuk menampung hasil perhitungan.

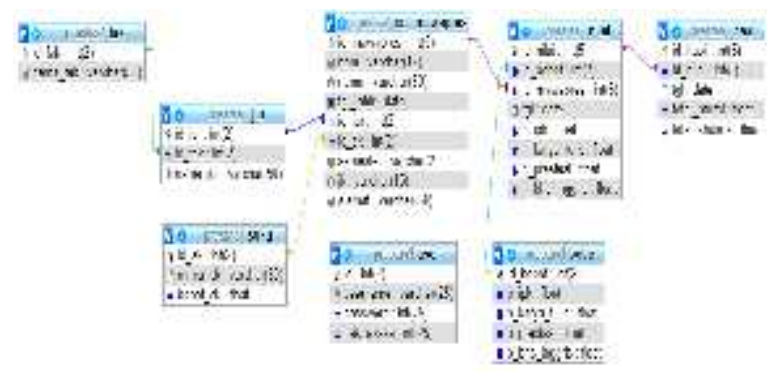

Gambar 1. Relasi Antar Tabel

\subsection{Diagram Konteks}


Diagram konteks secara umum menggambarkan entitas luar yang terlibat, masukan yang dibutuhkan dan keluaran yang dihasilkan dar sistem yang akan dibuat. Entitas luar yang ada dalam sistem in adalah Admin, dan Juri, dapat dilihat pada gambar 3.3 dibawah ini:

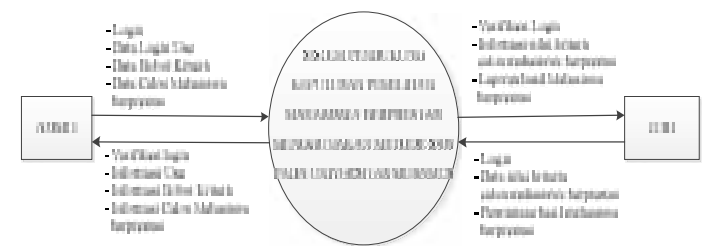

Gambar 2 Diagram Konteks

\subsection{DFD level 0}

DFD level 0 merupakan penjabaran dari diagram konteks yang telah dirancang sebelumnya. Proses yang ada pada sistem yang dibuat yaitu proses 1.0 sampai proses 10.0 .

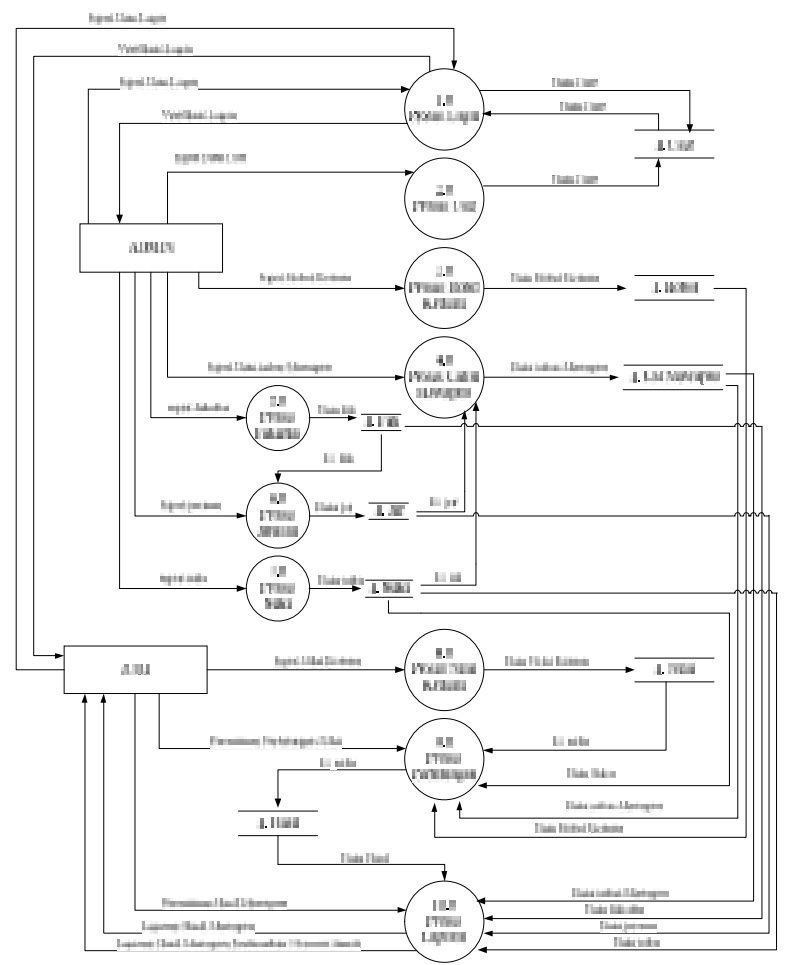

Gambar 3 DFD Level 0

\subsection{DFD Level 1 Proses Laporan}

Penjabaran proses 10.0 proses laporan, yaitu sebagai berikut :

1. Proses 10.1
Proses ini merupakan proses Laporan hasil Mawapres.

2. Proses 10.2

Proses ini merupakan proses Laporan hasil Mawapres berdasarkan Otonom daerah.

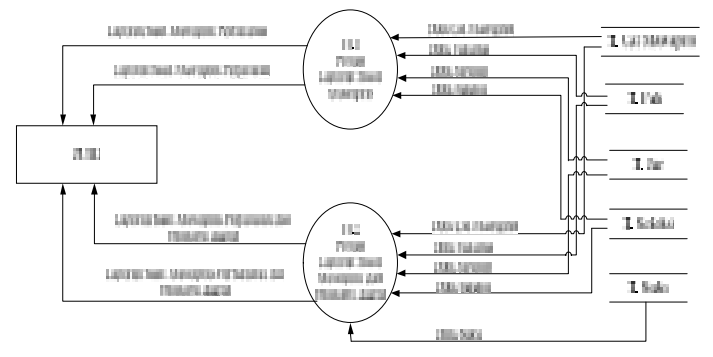

Gambar 4 DFD Level 1 Proses Laporan

\section{HASIL DAN PEMBAHASAN}

4.1 Hasil penelitian

Berdasarkan hasil penelitian dan pembuatan sistem pendukung keputusan pemilihan mahasiswa berprestas menggunakan metode SAW pada Universitas Musamus, maka rancangan sistem yang terdiri dar 8 tabel yang akan dibuat dalam bentuk website menggunakan Software Xamp Dan Sublime, aplikasi yang dapat melakukan proses penginputan data berupa data user, data peserta, data bobot dan data penilaian, serta mencetak hasil perangkingan pemilihan mahasiswa berprestasi.

\subsection{Pembahasan}

Pada pembahasan ini akan dibahas mengenai fasilitas yang diberikan sistem dan hasil pengujian sistem.

4.2.1 Fasilitas yang diberikan sistem

Sistem ini memiliki beberapa kebutuhan fungsional yang melengkapi fiturfitur dalam sistem. Berikut adalah kebutuhan fungsional dalam sistem :

1. Admin dapat menyimpan, menambah, mengedit, dan menghapus data calon mahasiswa berprestasi 
2. Admin dapat menyimpan, menambah, mengedit, dan menghapus data login

3. Admin dapat mengubah data bobot kriteria penilaian

4. Admin dapat login ke dalam Sistem

5. Juri dapat menyimpan, menambah, mengedit, dan menghapus nilai kriteria calon mahasiswa berprestasi

6. Juri dapat mencetak laporan hasil peringkat calon mahasiswa berprestasi

7. Juri dapat login ke dalam Sistem.

\subsubsection{Tampilan sistem}

\section{Halaman Utama Admin}

Halaman utama admin berfungs untuk melakukan pengelolahan data user, data calon mawapres dan data bobot kriteria.

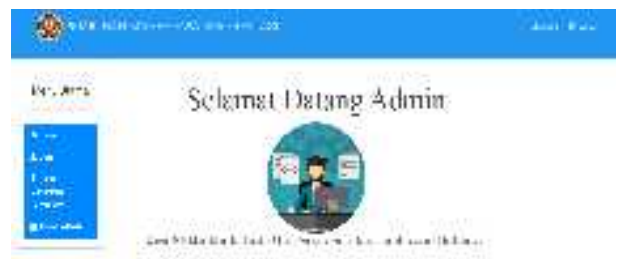

Gambar 5 Halaman Utama Admin

2. Halaman User

Halaman ini berfungsi untuk menampilkan, menambahkan, mengubah dan menghapus data user pada sistem.

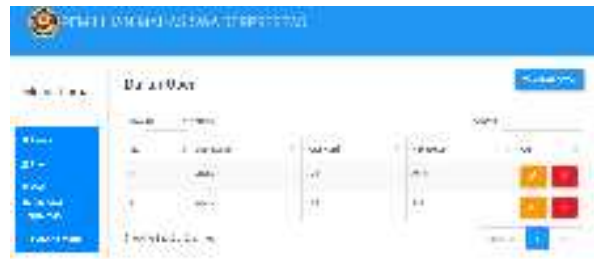

\section{Gambar 6 Halaman User}

3. Halaman Calon Mahasiswa Berprestasi

Halaman ini berfungsi untuk menampilkan, menambahkan, mengubah dan menghapus data calon mahasiswa berprestasi pada sistem

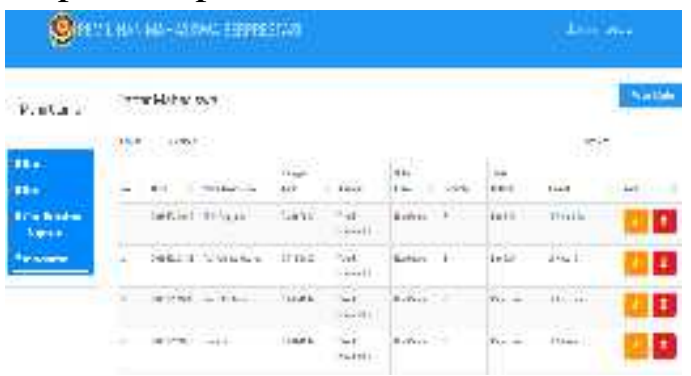

Gambar 7 Halaman Calon Mawapres

4. Halaman Bobot Kriteria

Halaman ini berfungsi untuk menampilkan, mengubah dan menghapus data bobot kriteria pada sistem.

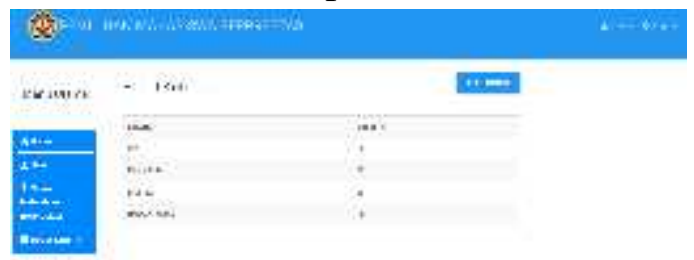

Gambar 8 Halaman Bobot Kriteria

5. Halaman Penilaian

Halaman ini berfungsi untuk menampilkan, menambahkan, mengubah dan menghapus data penilaian juri terhadap peserta mahasiswa berprestasi pada sistem.

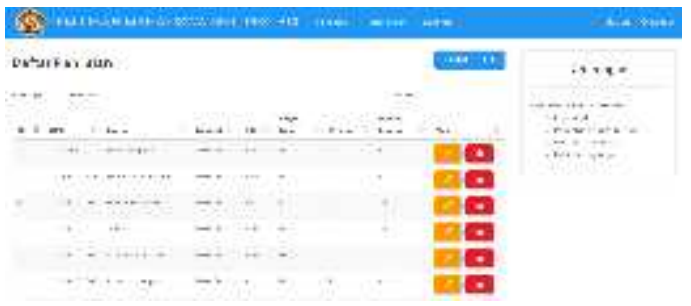

Gambar 9 Halaman Penilaian

6. Halaman Perhitungan

Halaman perhitungan befungsi untuk menampilkan hasil perhitungan Seleksi Mahasiswa Berprestasi menggunakan metode SAW, berdasarkan Tahun Perhitungan. 


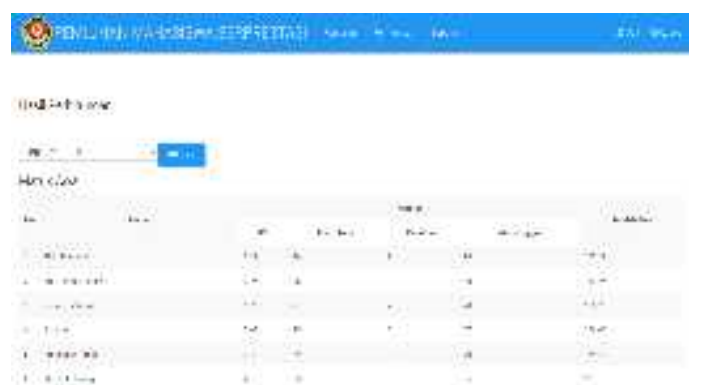

Gambar 10 Halaman Perhitungan

7. Halaman Laporan

Halaman laporan berfungsi untuk menampilkan informasi hasil perhitungan pemilihan mahasiswa berprestasi yang akan dicetak menjadi sebuah softcopy atau hardcopy.

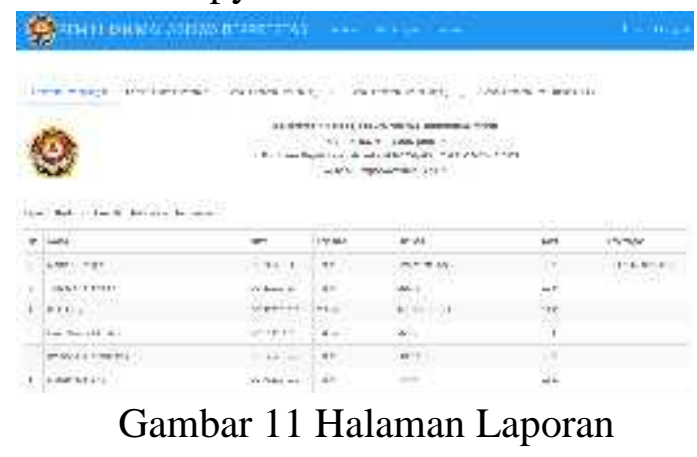

\subsubsection{Pengujian}

1. Pengujian BlackBox

Dalam pengujian ini, sistem pendukung keputusan pemilihan mahasiswa berprestasi menggunakan metode SAW pada Universitas Musamus, dilakukan pengujian fungsional, apakah semua fungsi-fungsi dapat berjalan baik sesuai dengan perancangan sistem.

Dari hasil pengujian blackbox dapat menunjukan bahwa sistem pendukung keputusan pemilihan mahasiswa berprestasi menggunakan metode SAW pada Universitas Musamus, dapat dijalankan sesuai dengan yang diharapkan untuk mendukung BAKK dan Juri sebagai tim penilai dalam program pemilihan mahasiswa berprestasi pada Universitas Musamus.
2. Pengujian Perbandingan Perhitungan SAW

Pengujian ini bertujuan untuk membandingkan hasil perhitungan metode SAW antara hasil perhitungan pada sistem dengan hasil perhitungan pada Microsoft Excel 2010. Pada dasarnya pengujian ini ialah hasil perhitungan yang akan dibandingkan harus mengikut hasil perhitungan distribus normal. Berikut pengujian perbandingan perhitungan yang telah dilakukan :

a. Perhitungan menggunakan Microsoft Excel

- Matriks Normalisasi

Membuat normalisas matrik berdasarkan persamaan yang disesuaikan dengan jenis atribut, sehingga diperoleh matrik ternormalisasi.

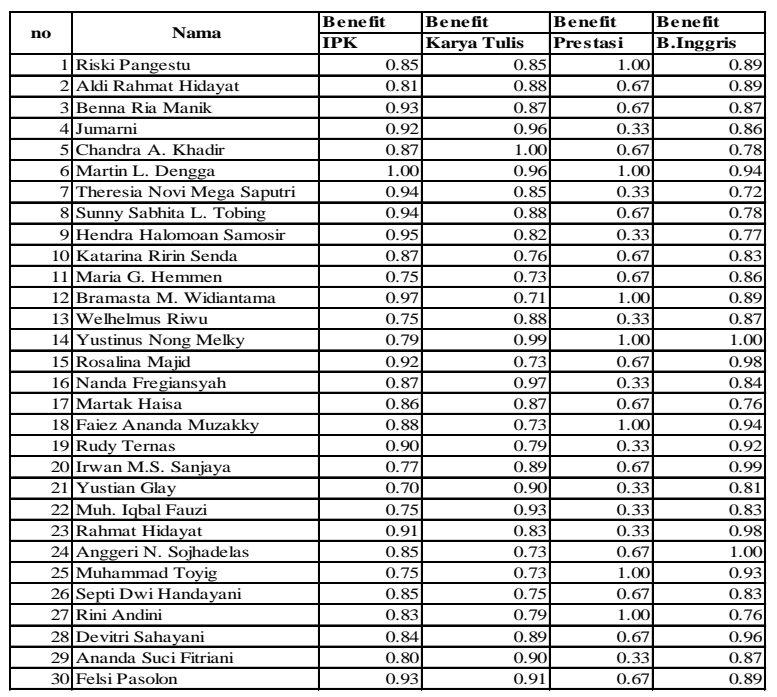

Gambar 12 Matriks Normalisasi

- Perangkingan

Perangkingan yaitu penjumlahan dari perkalian matrik ternormalisasi dengan vector bobot sehingga diperoleh nilai terbesar yang dipilih sebagai alternatif terbaik. 


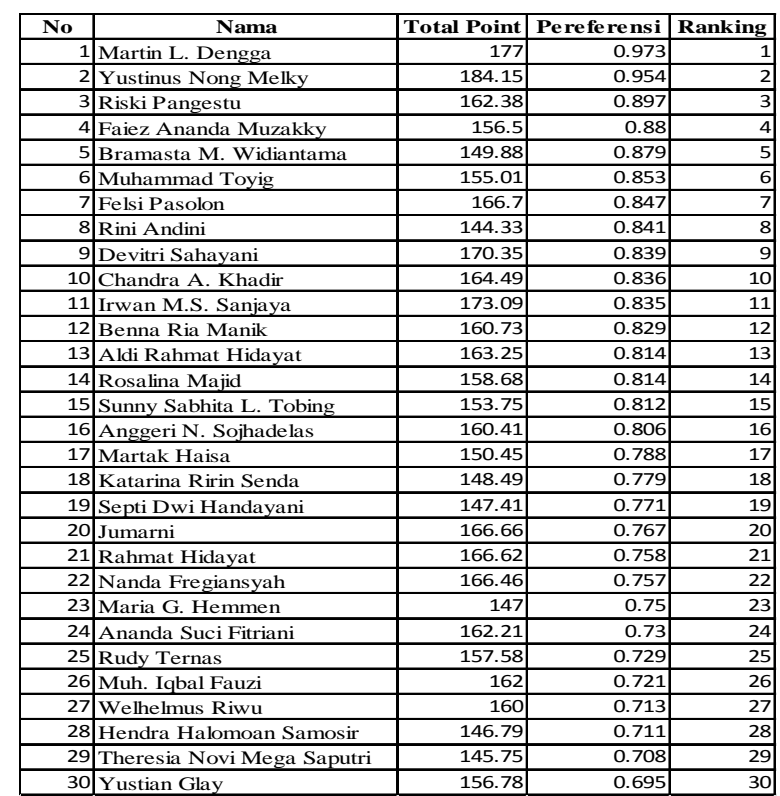

Gambar 13 Perangkingan

\section{b. Perhitungan Menggunakan Sistem}

- Matriks Normalisasi

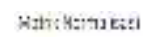

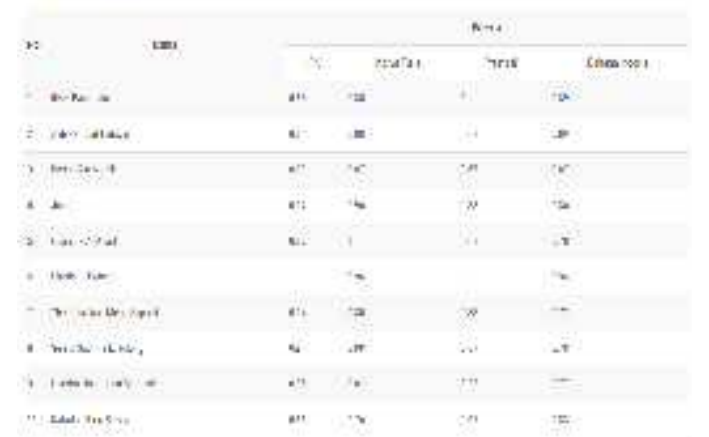

Gambar 16 Matriks Normalisasi Pada Sistem

\section{- Perangkingan}

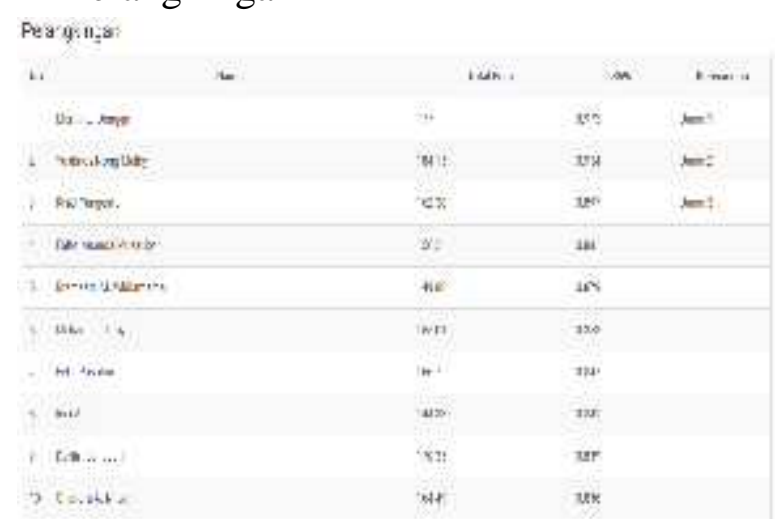

Gambar 17 Perangkingan Pada Sistem

Hasil perbandingan sistem yang dibuat dengan Ms. Excel :
- Penjumlahan hasil perhitungan SAW pada sistem sama dengan hasil perhitungan SAW pada Ms. Excel.

- Waktu yang diperlukan sistem untuk perhitungan SAW lebih cepat dibandingkan Ms.Excel yaitu 05.7 detik, sedangkan waktu yang diperlukan Ms.Excel untuk perhitungan SAW yaitu 18.5 detik, dengan selis waktu keduanya yaitu 12.8 detik.

- Perhitungan menggunakan Ms.Excel proses yg dilakukan tidak secepat sistem yg dibuat, karena pada excel apabila terdapat penambahan data, harus menambah sheet yang baru dan tu memerlukan proses tambahan serta pembuatan laporan Ms.Excel membutuhkan tempat atau lembar yang lebih banyak di bandingkan menggunakan sistem yang dibuat, karena dengan sistem yang dibuat walau adanya penambahan data, sistem secara otomatis akan menambah proses perhitungan dan untuk laporan lebih menghemat tempat.

\section{KESIMPULAN}

Pengujian sistem menggunakan metode black box dan metode perbandingan perhitungan SAW pada sistem pendukung keputusan pemilihan mahasiswa berprestasi menggunakan metode SAW pada Universitas Musamus menunjukan kelayakan implementasi sistem. Maka kesimpulan yang dapat diambil dari penelitian ini yaitu:

1. Sistem yang dibuat dapat mempercepat proses pengolahan data pemilihan mahasiswa berprestasi.

2. Sistem yang dibuat dapat menyimpan data mengena proses pemilihan mahasiswa berprestasi.

3. Penerapan perhitungan menggunakan metode SAW pada sistem yang dibuat dapat memberikan rekomendas 
mahasiswa berprestas berdasarkan bobot kriteria yang sudah ditentukan.

\section{DAFTAR PUSTAKA}

[1] W. Didin, "Pedoman Pemilihan Mahasiswa Berprestasi Sarjana Tahun 2019," RISTEKDIKTI, pp. 1-40, 2019.

[2] U. Musamus, "Universitas Musamus Merauke - Profil UNMUS,” 2019. .

[3] Frieyadie, "Penerapan Metode Simpe Additive Weighting (SAW) Dalam Sistem Pendukung Keputusan Promosi Kenaikan Jabatan," J. Pilar Nusa Mandiri, vol. 11, no. 1, pp. 37-45, 2016.

[4] M. Hindayati and H. Hirzi Nur, "Sistem Pendukung Keputusan Penentuan Mahasiswa Berprestasi di Universitas Muhammadiyah Purwokerto Menggunakan Metode Weighted Product ( WP )," Juita, vol. 5, no. 1, pp. 51-61, 2017.

[5] E. Sri, "Perancangan Sistem Pendukung Pengambilan Keputusan untuk Penerimaan Beasiswa dengan Metode SAW (Simple Additive Weighting)," Teknol. Inf. Din., vol. 16, no. 2 , p. 7, 2011.

[6] S. Wiji, Konsep Sistem Pendukung Keputusan. Malang, 2015.

[7] M. M Sidi, F. Roeri Fajri, and R. Hendra, "Pengujian Aplikasi Menggunakan Black Box Testing Boundary Value ANALYSIS ( Studi Kasus : Aplikasi Prediksi Kelulusan SNMPTN)," JITTER (Jurnal Ilm. Teknol. Inf. Ter., vol. I, no. 3, pp. 3136, 2015.

[8] S. Suwarjono and S. Susanto, "Sistem Penjadwalan Perkuliahan Pada
Universitas Musamus Menggunakan Algoritma Genetika Berbasis Web," Musamus J. Res. Inf. Commun.

Technol., vol. 1, no. 1, pp. 12-17, Nov. 2018. 